\title{
THE LEITNERIACEAE IN THE SOUTHEASTERN UNITED STATES ${ }^{1}$
}

\author{
R. B. Channell and C. E. Wood, Jr.
}

LEITNERIACEAE Bentham in Bentham \& Hooker,

Gen. Pl. 3: vi, 396. 1880, "Leitnerieae," nom. cons.

\section{(CoRkwood Family)}

A monotypic family distinguished by secretory canals in the pith and leaves, nonaromatic foliage, erect catkins, single-styled gynoecium with a superior, 1-locular ovary, single parietal anatropous ovule, and seed with a large embryo and thin, fleshy endosperm.

\section{Leitneria Chapman, Fl. So. U. S. 427. 1860.}

Dioecious deciduous shrub or small tree to $6 \mathrm{~m}$. tall, up to $15 \mathrm{~cm}$. in diameter; current stems hairy; bark brown; wood very light in weight. Leaves alternate, 5-ranked, simple, exstipulate, pubescent; blades 10-15 $\mathrm{cm}$. long, lanceolate to elliptic-lanceolate, acute, entire, somewhat coriaceous and glossy in age, finally rugose; petioles half-cylindric, ca. $2.5 \mathrm{~cm}$. long; nodes with 3 traces from 3 gaps. Flowers appearing before the leaves in erect, preformed aments with weak axes. Staminate catkins curving outward, the axis lax, with 40-50 cymules in the axils of spirally deltoidovate scales, each cymule of (3-) 10-12(-15) free stamens (apparently representing about 3 flowers); bracteoles and perianth absent; filaments short, slightly dilated at the base; anthers oblong, 2-locular at anthesis, slightly versatile, nearly extrorse, dehiscing longitudinally; pollen nearly globose, smooth, 3-6-colpate. Carpellate catkins stiffly erect, spikelike,

\footnotetext{
${ }^{1}$ Prepared for a generic flora of the southeastern United States, a joint project of the Gray Herbarium and the Arnold Arboretum made possible through the support of George R. Cooley and the National Science Foundation. This treatment was prepared originally by the first author while he was associated with the Arnold Arboretum and the Gray Herbarium; it has been edited by the second author in the style developed since that time and has been modified through the incorporation of additional information. The scheme follows that outlined at the beginning of the series (Jour. Arnold Arb. 39: 296-346. 1958). As in former treatments, the area covered is bounded by and includes North Carolina, Tennessee, Arkansas, and Louisiana. References which we have not verified are marked with an asterisk. The illustration was prepared by Dorothy $\mathrm{H}$. Marsh from living plants cultivated at the Arnold Arboretum and from fresh material kindly collected for us on the Apalachicola River by Dr. Robert K. Godfrey, of Florida State University. We are further grateful to Dr. Wilbur H. Duncan, of the University of Georgia, for information on the occurrence of Leitneria in Georgia, and to Dr. Delzie Demaree, of Hot Springs, Arkansas, for data from that state and from Missouri.
} 
relatively few flowered; carpellate flowers sessile, solitary in the axils of the spirally arranged primary bracts, each with 2 bractlets at the base and surrounded by a perianth (involucre) of (3) $4(-8)$ minute tepals (scales?) (2 often somewhat larger than the others); style linear-lanceolate, reddish, deciduous, the grooved stigmatic surface facing the bract; ovary superior, ovoid, green, 1-locular with a single parietal, pendulous, anatropous, 2integumented ovule on the side toward the bract; embryo sac of the "Polygonum" type. Fruit an erect, smooth, oblong-ovoid, somewhat compressed, dry drupe (the thin flesh heavily reticulated with vascular bundles), chestnut-brown, green when young, with a terminal stylar scar. Seed with a thin layer of endosperm and a large, straight embryo. Type species: L. floridana Chapm. (Named for Dr. E. T. Leitner, -1838, a German naturalist who traveled in Florida and was killed during the Seminole War.) - CORKWOOD.

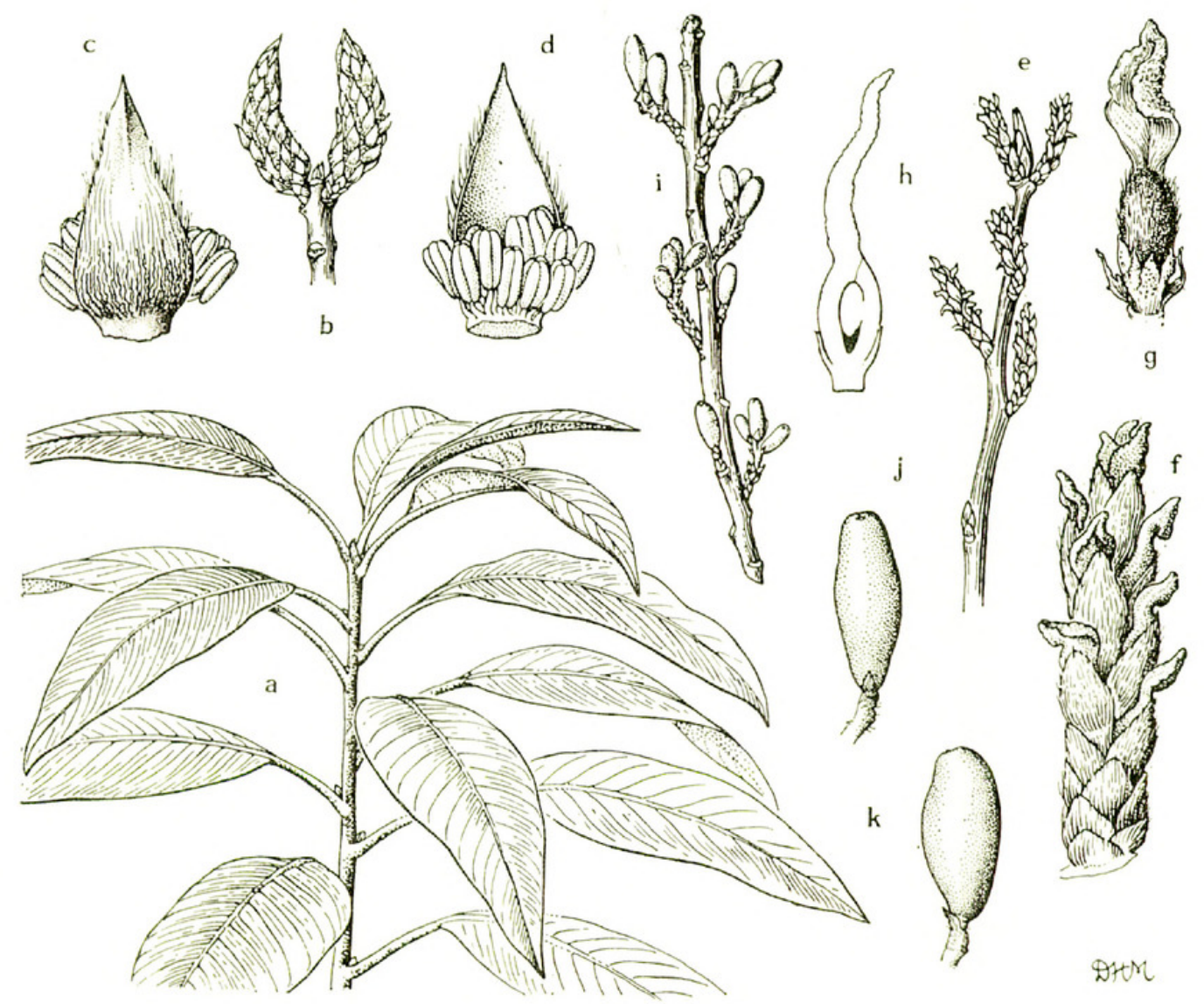

FIG. 1. Leitneria. $a-k$, L. floridana: a, vegetative shoot, $\times 1 / 4 ; b$, twig with staminate catkins, $\times \mathrm{I} / 2 ; \mathrm{c}$, d, bracts of staminate catkin from without and within, showing stamens, $\times 4$; e, twig with carpellate catkins, $\times 1 / 2 ; \mathrm{f}$, carpellate catkin, $\times 3$; g, carpellate flower with subtending bract removed, stigmatic surface toward viewer - note tepals and two lateral bractlets, $X 4$; h, carpellate flower in vertical section, stigmatic surface to the right, micropyle of ovule at top, diagrammatic, $\times 4$; , twig with immature fruits, $\times 1 / 2 ; j, \mathrm{k}$, mature fruits, $\times 1$. 
A single species, Leitneria floridana, known from muddy, brackish tidal shores, river swamps, swampy prairies, and sloughs ${ }^{2}$ in scattered localities in three widely separated areas: southern Georgia (McIntosh and Dougherty counties) and northern Florida (Clay, Franklin and Levy counties); southeastern Missouri (Butler, Dunklin, Pemiscot, and Ripley counties) and eastern Arkansas (Arkansas, Clay, Craighead, Jackson, Jefferson, and Lincoln counties); and southeastern Texas (Brazoria and Chambers counties).

According to the literature, the species is variable in respect to height, leaf shape, length of catkins, and fruit size, but no comprehensive study of variation has been made, and no formal taxonomic segregates have been proposed.

Individual plants spread clonally, apparently from adventitious buds on the shallow root system. Pollination is by wind, and fruits are not set in the absence of pollination. Sometimes cultivated as an ornamental oddity in appropriate wet situations, the Missouri form is hardy as far north as Boston, Massachusetts, and Rochester, New York. The soft, only slightly porous wood, the lightest of any North American plant (sp. gr. 0.21 ) has sometimes been used locally for floats on fishing nets.

Generally admitted to be highly specialized (reduced) in structure, Leitneria shows few features which assist in determining its relationships. It has been associated with Ranales, Rosales, Geraniales, Sapindales, Parietales, and Myricales, and in most modern works it is placed in the "Amentiferae," usually as a separate order in a position close to Myricales, despite various lines of evidence to the contrary. Comparative morphological, anatomical, and embryological studies indicate that the closest relationships may be with the primitive Rosales (including Hamamelidaceae) or Geraniales, but more diagnostic evidence from these groups is needed. The development of the male gametophyte and fertilization have not been studied, and the chromosome number is unknown.

Vascular and other evidence suggests that the flower of Leitneria is derived from a bisexual ancestral form with a perianth of two cycles, at least one cycle of stamens, and a 2-carpellate, perhaps apocarpous, gynoecium. The staminate inflorescence apparently represents a many-flowered compound ament with a cymule of three florets in the axil of each primary bract.

The secondary xylem is so advanced in various respects, including the simple perforation plates and the alternate pit arrangement on the side walls of the vessel elements, that there would be little difficulty in deriving it from that of the primitive types of any of the groups with which

\footnotetext{
${ }^{2}$ Dr. Delzie Demaree has written to Channell (April 1, 1962) of an exceptional colony of Leitneria in valley farmland on the property of Mr. Ronney G. Mattics about 2 $1 / 4$ miles east of Senath, Dunklin County, Missouri. "The area has been cleared of large Taxodium trees. Waste areas and fence rows are covered by Leitneria. These plants are a troublesome weed to this farmer. ... I have watched this area for over ten years and before any of it was cleared thousands of plants were present. The soil is sandy loam and fertile." The plants in the area are three to five feet tall and were in abundant flower.
} 
Leitneria has been associated. The most distinctive anatomical feature is the presence of secretory canals in the outer part of the pith which extend in association with the vascular bundles throughout the leaves. This and the stratified phloem led Solereder to note the similarity to Dipterocarpaceae, from which, however, it must be excluded on other grounds. (See Metcalfe \& Chalk; Heim; Van Tieghem \& Le Conte.)

\section{REFERENCES :}

AbBe, E. C., \& T. T. EARLE. Inflorescence, floral anatomy and morphology of Leitneria floridana. Bull. Torrey Bot. Club 67: 173-193. 1940.

Baillon, H. Castanéacées. Hiist. Pl. 6: 217-259. 1875. [Leitneria, 239-241; carpellate flowers incorrectly drawn.]

Bentham, G., \& J. D. Hooker. Leitnerieae. Gen. Pl. 3: 396, 397. 1880.

Candolle, C. de. Myricaceae. Prodr. 16(2): 147-155. 1864. [Leitneria, 154.]

Dunbar, J. Leitneria floridana. Gard. Chron. III. 47: 228. 1910. [Use as an ornamental.]

Engler, A. Leitneriaceae. Nat. Pflanzenfam. III. 1: 28, 29. 1894; Nachträge II-IV. 117, 363. 1897.

Heim, F. Sur le genre: Leitneria Chapm. Assoc. Fr. Avanc. Sci. Congr. Marseille 1891. 16 pp. 2 pls. Paris. 1892. [Allies Leitneria with Hamamelidaceae; carpellate flowers incorrectly illustrated, as in Baillon.]

Recherches sur les Diptérocarpacées. ii +186 pp. pls. 1-11. Paris. 1892. [Leitneria, 175, 176, pls. 10, 11; excluded from Dipterocarpaceae; illustrations as above.]

HJeimevist, H. Studies on the floral morphology and phylogeny of the Amentiferae. Bot. Not. Suppl. 2: 1-171. 1948. [Comparative morphology; Leitneria, 71-76, retained as order Leitneriales in Amentiferae nearest Myricaceae.]

Metcalfe, C. R., \& L. Chalk. Leitneriaceae. Anat. Dicot. 2: 1282, 1283. 1950.

Oliver, D. Leitneria floridana, Chapm. Hooker's Ic. Pl. 11: 33, 34. pl. 1044. $1867-1871$.

Pasfield, D. H. Leitneria floridana. Gard. Chron. III. 107: 185. 1940.

Pfeiffer, W. M. The morphology of Leitneria floridana. Bot. Gaz. 53: 189-203. pls. 18-20. 1912. [Includes $q$ gametophyte and embryology.]

Sargent, C. S. Leitneria. Silva N. Am. 7: 109-112, pl. 330. 1895.

Solereder, H. Systematische Anatomie der Dicotyledonen. xvi + 984 pp. Stuttgart. 1899. [Leitnerieae, 879, 880.]

Tieghem, P. van, \& H. Le Conte. Structure et affinités du Leitneria. Bull. Soc. Bot. Fr. 33: 181-184. 1886. [Assigned to Dipterocarpaceae.]

Trelease, W. Leitneria floridana. Missouri Bot. Gard. Rep. 6: 65-90. front., pls. 30-44. 1895. [Comprehensive morphological study; wood anatomy.]

Department of Biology,

VANDERBILT UNIVERSITY

AND

The Arnold Arboretum, HARVARD UNIVERSITY 


\section{$2 \mathrm{BHL}$ Biodiversity Heritage Library}

Channell, R. B. and Wood, Carroll E. 1962. "The Leitneriaceae in the southeastern United States." Journal of the Arnold Arboretum 43(4), 435-438. https://doi.org/10.5962/bhl.part.20439.

View This Item Online: https://www.biodiversitylibrary.org/item/33619

DOI: https://doi.org/10.5962/bhl.part.20439

Permalink: https://www.biodiversitylibrary.org/partpdf/20439

\section{Holding Institution}

Missouri Botanical Garden, Peter H. Raven Library

\section{Sponsored by}

Missouri Botanical Garden

\section{Copyright \& Reuse}

Copyright Status: In copyright. Digitized with the permission of the rights holder.

Rights Holder: Arnold Arboretum of Harvard University

License: http://creativecommons.org/licenses/by-nc-sa/3.0/

Rights: https://biodiversitylibrary.org/permissions

This document was created from content at the Biodiversity Heritage Library, the world's largest open access digital library for biodiversity literature and archives. Visit BHL at https://www.biodiversitylibrary.org. 